University of South Florida

DIGITAL COMMONS

Digital Commons @ University of

@ UNIVERSITY OF SOUTH FLORIDA

South Florida

$1-1-2013$

\title{
2013 Accountability Report USF Sarasota-Manatee
}

USF

Follow this and additional works at: https://digitalcommons.usf.edu/usf_accountability_reports

\section{Scholar Commons Citation}

USF, "2013 Accountability Report USF Sarasota-Manatee" (2013). USF Accountability Reports. 34.

https://digitalcommons.usf.edu/usf_accountability_reports/34

This Article is brought to you for free and open access by the USF Archives at Digital Commons @ University of South Florida. It has been accepted for inclusion in USF Accountability Reports by an authorized administrator of Digital Commons @ University of South Florida. For more information, please contact digitalcommons@usf.edu. 


\section{2-13 \\ Annual Accountability Report}

\section{UNIVERSITY OF SOUTH FLORIDA SARASOTA-MANATEE}

STATE UNIVERSITY SYSTEM of FLORIDA Board of Governors 


\section{$\underline{\text { TABLE OF CONTENTS }}$}

\section{EXECUTIVE SUMMARY}

DASHBOARD

p. 2

KEY ACHIEVEMENTS

p. 5

NARRATIVE

p. 6

\section{DATA TABLES}

SECTION 1. FINANCIAL RESOURCES p. 14

SECTION 2. PERSONNEL p. 18

SECTION 3. ENROLLMENT p. 19

SECTION 4. UNDERGRADUATE EDUCATION p. 21

SECTION 5. GRADUATE EDUCATION p. 29

SECTION 6. RESEARCH \& ECONOMIC DEVELOPMENT p. 32 


\section{Dashboard}

\begin{tabular}{|c|c|c|c|c|c|c|c|c|}
\hline $\begin{array}{l}\text { Headcount } \\
\text { Enrollments }\end{array}$ & $\begin{array}{l}\text { Fall } \\
2012\end{array}$ & $\begin{array}{l}\% \\
\text { Total }\end{array}$ & $\begin{array}{l}2007-2012 \\
\% \text { Change }\end{array}$ & \multicolumn{3}{|c|}{ Degree Programs Offered } & \multicolumn{2}{|c|}{2012 Carnegie Classifications } \\
\hline TOTAL & 1,952 & $100 \%$ & $6 \%$ & \multicolumn{2}{|c|}{ TOTAL (as of Spring 2013) } & 24 & \multirow{2}{*}{ Basic: } & \multirow{2}{*}{$\begin{array}{l}\text { Master's Colleges and } \\
\text { Universities (medium) }\end{array}$} \\
\hline White & 1,459 & $75 \%$ & $-4 \%$ & \multicolumn{2}{|c|}{ Baccalaureate } & 16 & & \\
\hline Hispanic & 242 & $12 \%$ & $124 \%$ & \multicolumn{2}{|l|}{ Master's } & 8 & \multirow{2}{*}{$\begin{array}{l}\text { Undergraduate } \\
\text { Instructional Program: }\end{array}$} & \multirow{2}{*}{$\begin{array}{l}\text { Professions plus arts \& } \\
\text { sciences, some graduate }\end{array}$} \\
\hline Black & 127 & $7 \%$ & $9 \%$ & \multicolumn{2}{|l|}{ Research Doctorate } & 0 & & \\
\hline Other & 124 & $6 \%$ & $19 \%$ & \multicolumn{2}{|c|}{ Professional Doctorate } & 0 & \multirow{2}{*}{$\begin{array}{l}\text { Graduate } \\
\text { Instructional Program: }\end{array}$} & \multirow{2}{*}{$\begin{array}{l}\text { Post-baccalaureate with arts } \\
\text { \& sciences (education dominant) }\end{array}$} \\
\hline Full-Time & 843 & $43 \%$ & $16 \%$ & \multirow{2}{*}{$\begin{array}{l}\text { Faculty } \\
\text { (Fall 2012) }\end{array}$} & \multirow{2}{*}{$\begin{array}{l}\text { Full- } \\
\text { Time }\end{array}$} & \multirow{2}{*}{$\begin{array}{l}\text { Part- } \\
\text { Time }\end{array}$} & & \\
\hline Part-Time & 1,109 & $57 \%$ & $-1 \%$ & & & & \multirow{2}{*}{ Size and Setting: } & \multirow{2}{*}{$\begin{array}{l}\text { Small four-year, primarily } \\
\text { nonresidential }\end{array}$} \\
\hline Undergraduate & 1,712 & $88 \%$ & $24 \%$ & TOTAL & 57 & 64 & & \\
\hline Graduate & 140 & $7 \%$ & $-57 \%$ & Tenure \& Ten. Track & 35 & 0 & \multirow{2}{*}{$\begin{array}{l}\text { Community } \\
\text { Engagement: }\end{array}$} & \multirow{2}{*}{$\mathrm{n} / \mathrm{a}$} \\
\hline Unclassified & 100 & $5 \%$ & $-26 \%$ & Non-Tenured Faculty & 22 & 64 & & \\
\hline
\end{tabular}

\section{DEGREE PRODUCTIVITY AND PROGRAM EFFICIENCY}

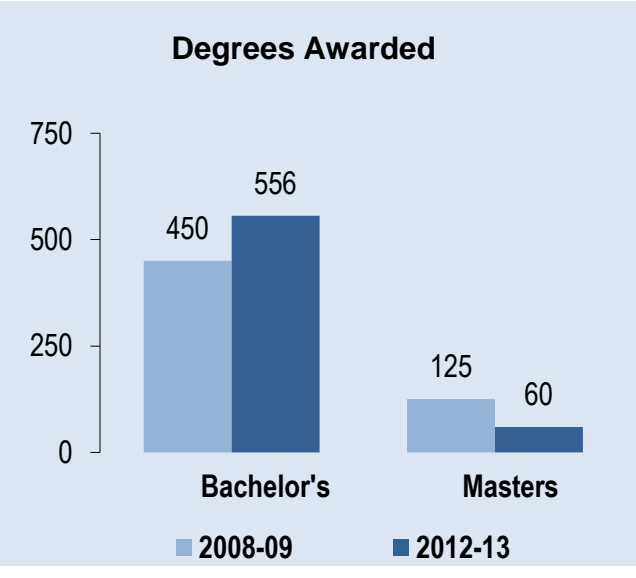

\section{Graduation Rates by Student Type}

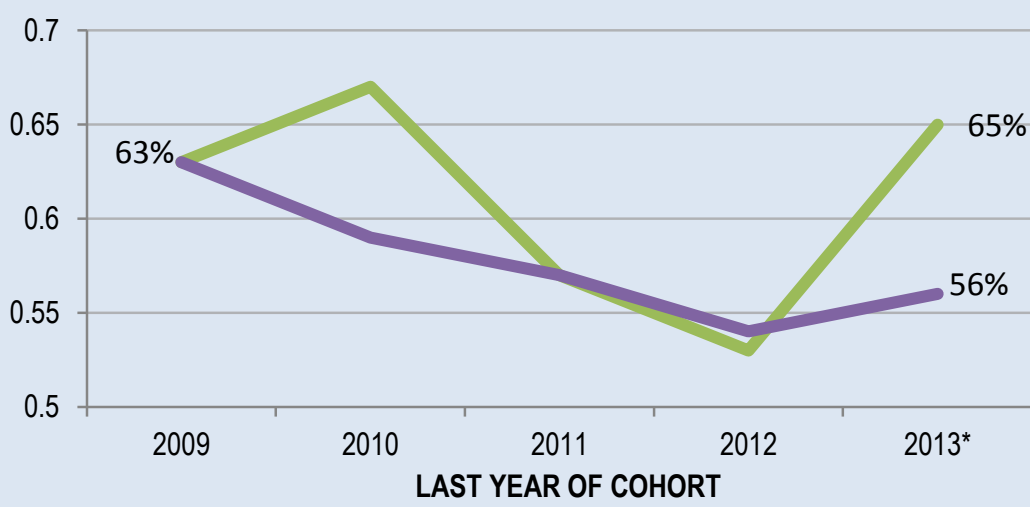

4yr AA Transfers

5yr Other Transfers

COHORT SIZES FOR COHORTS ENDING IN 2013
Bachelor's Degrees by Group

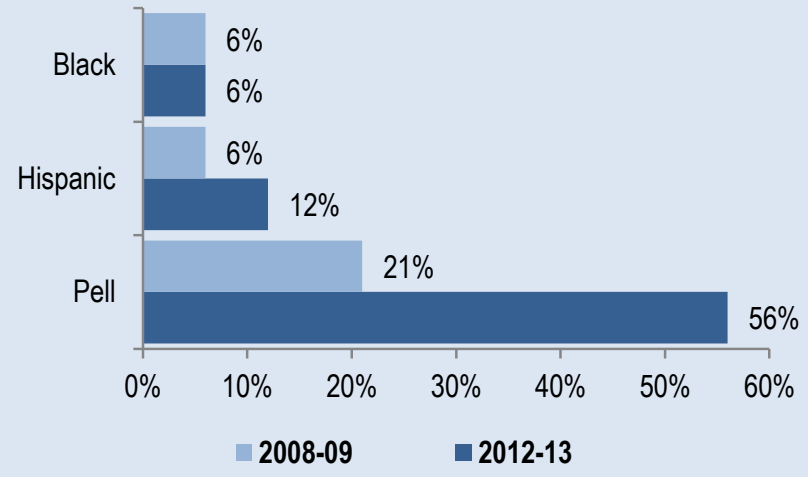

2012-13 Bachelor's Degrees Without Excess Hours

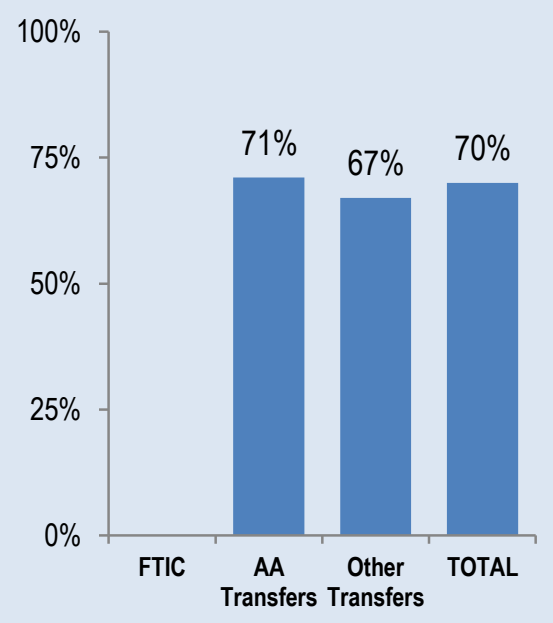




\section{Dashboard}

\section{DEGREES AWARDED IN PROGRAMS OF STRATEGIC EMPHASIS}
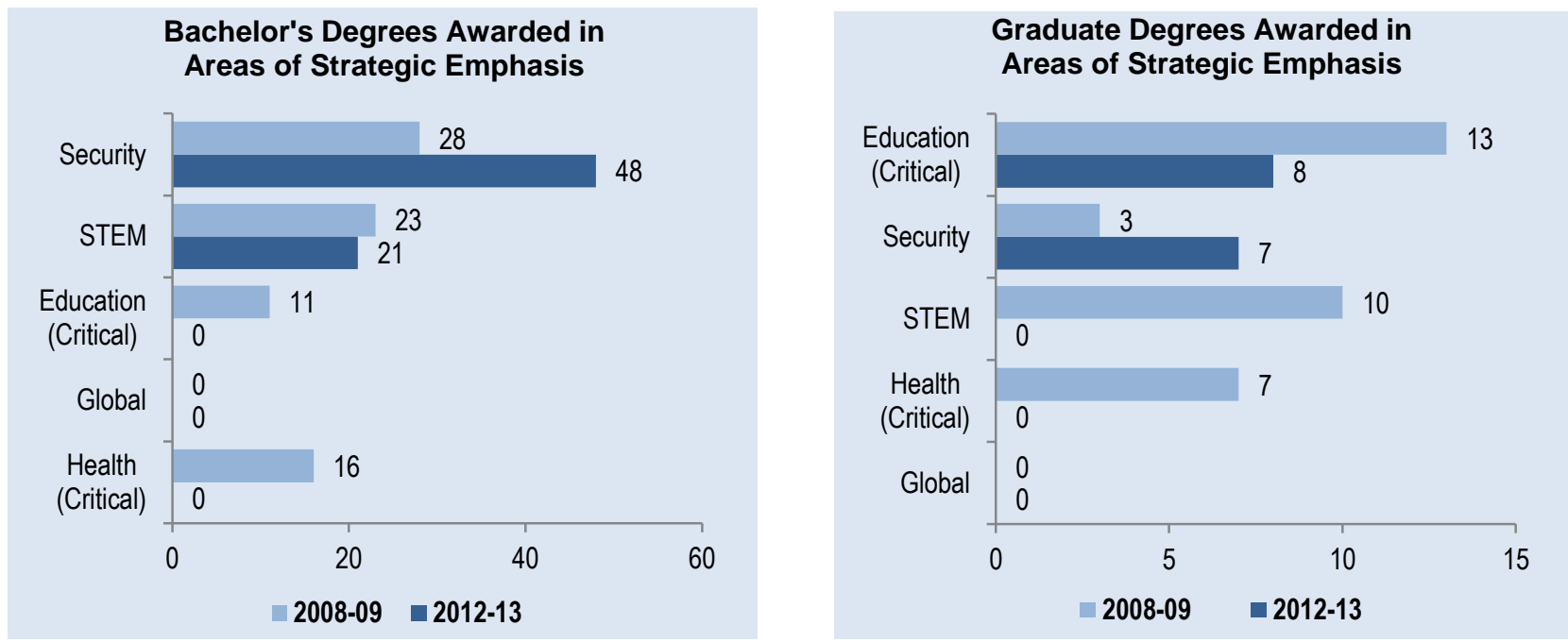

RESEARCH AND COMMERCIALIZATION ACTIVITY

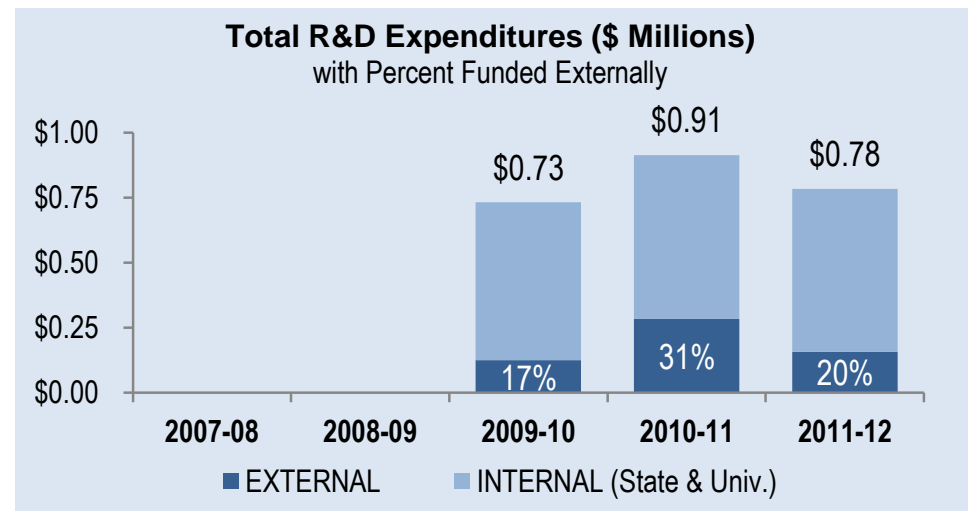

RESOURCES

\begin{tabular}{|c|c|c|c|c|c|}
\hline \multicolumn{6}{|c|}{ Appropriated Funding Per Actual US FTE } \\
\hline $\begin{array}{l}\$ 14,000 \\
\$ 12,000\end{array}$ & $\$ 12,734$ & $\$ 11,809$ & $\$ 12,480$ & $\$ 11,681$ & $\$ 11,520$ \\
\hline$\$ 10,000$ & \multirow{4}{*}{$75 \%$} & \multirow[b]{4}{*}{$70 \%$} & \multirow[b]{4}{*}{$65 \%$} & \multirow[b]{4}{*}{$61 \%$} & \multirow[b]{4}{*}{$56 \%$} \\
\hline$\$ 8,000$ & & & & & \\
\hline$\$ 6,000$ & & & & & \\
\hline $\begin{array}{l}\$ 4,000 \\
\$ 2,000\end{array}$ & & & & & \\
\hline$\$ 0$ & 2008-09 & 2009-10 & 2010-11 & 2011-12 & $2012-13$ \\
\hline TOTAL & $\$ 12,734$ & $\$ 11,809$ & $\$ 12,480$ & $\$ 11,681$ & $\$ 11,520$ \\
\hline TUITION & $\$ 3,228$ & $\$ 3,490$ & $\$ 4,374$ & $\$ 4,548$ & $\$ 5,122$ \\
\hline STATE & $\$ 9,506$ & $\$ 8,319$ & $\$ 8,105$ & $\$ 7,132$ & $\$ 6,398$ \\
\hline
\end{tabular}

Note: Tuition is the appropriated budget authority, not the amount actually collected. This tuition data does not include non-instructional local fees. State includes General Revenues, Lottery and Other Trust funds (i.e., Federal Stimulus for 2009-10 and 2010-11 only). State funded financial aid programs that follow the student are included in tuition data. Student FTE are actual (not funded) and based on the national definition. 


\section{Dashboard}

\section{POST-GRADUATION METRICS}
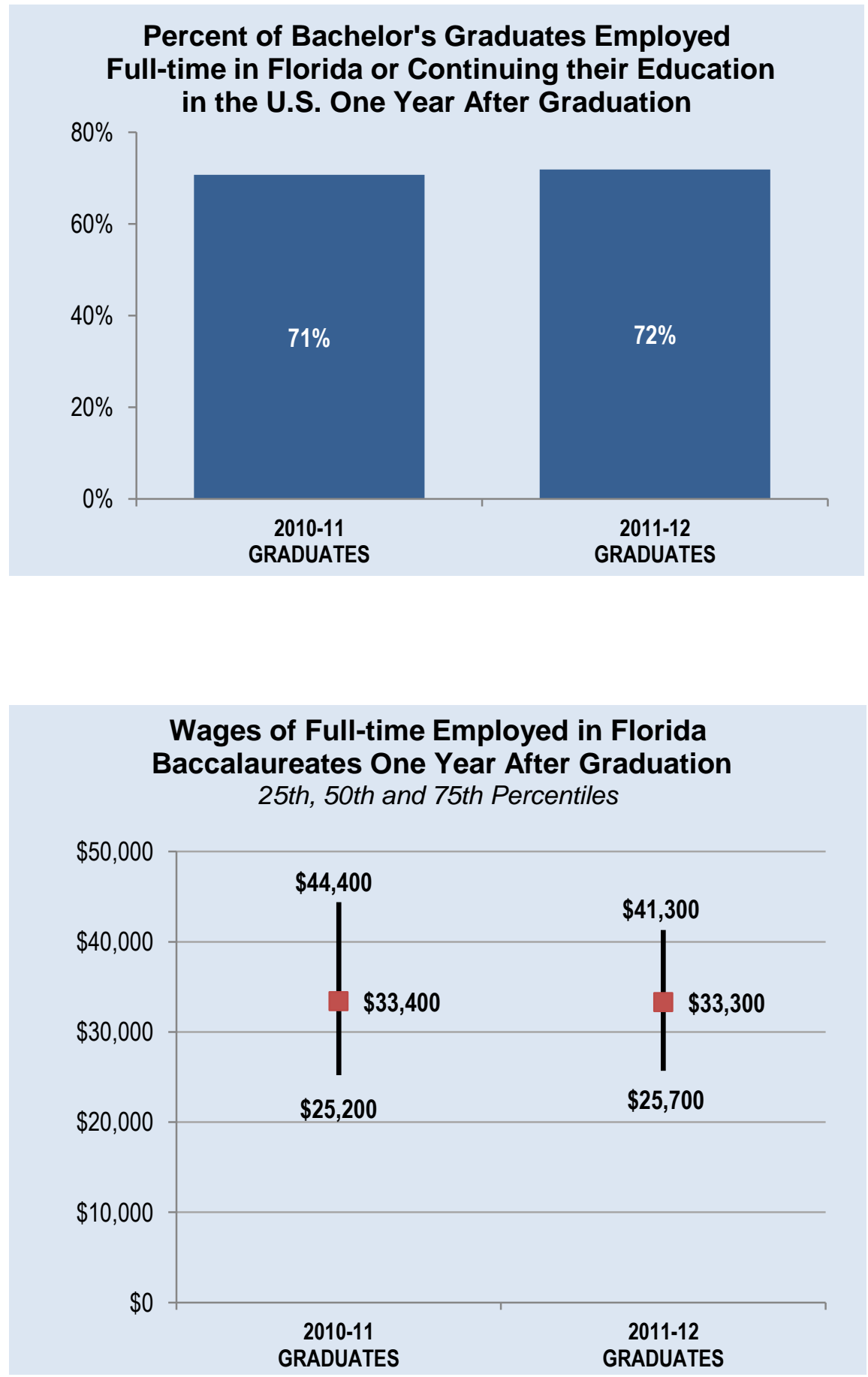

Notes: Percentages are based on the number of recent baccalaureate graduates who are either employed full-time in Florida (based on FETPIP data) or continuing their education in the U.S. (based on the National Student Clearinghouse data). Full-time employment is based on those who earned more than a full-time (40hrs a week) worker making minimum wage. Due to limitations in the data, the continuing enrollment data includes any enrollment the following year regardless of whether the enrollment was post-baccalaureate or not. These data account for $90 \%$ and $89 \%$ of the total graduating class for 2010-11 and 2011-12, respectively. BOG staff are actively working on adding non-Florida employment data to this measure for future reports.
Notes: Wage data is based on Florida's annualized Unemployment Insurance (UI) wage data for those graduates who earned more than a full-time employee making minimum wage in the fiscal quarter a full year after graduation. This wage data excludes graduates who were enrolled, regardless of their earnings. This UI wage data does not include individuals who are self-employed, employed out of state, employed by the military or federal government, or those without a valid social security number. These data account for $61 \%$ and $62 \%$ of the total graduating class for 2010-11 and $2011-12$, respectively. Wages rounded to nearest hundreds. 


\section{Key Achievements (2012-2013)}

\section{STUDENT AWARDS/ACHIEVEMENTS}

1. Four USFSM students were accepted from more than 3,000 applications to present their research at the National Conference for Undergraduate Research (NCUR) in March 2013.

\section{FACULTY AWARDS/ACHIEVEMENTS}

1. Dr. Jennifer Mariano, Associate Professor, was invited to serve on the Advisory Council of the Work on Purpose of Echoing Green, a New York City based not-for-profit organization.

\section{PROGRAM AWARDS/ACHIEVEMENTS}

1. USFSM Center of Partnerships for Arts-Integrated Teaching (PAInT) received a $\$ 42,000$ grant from the Manatee Community Foundation to fund a collaborative pilot program with Manatee County school district to incorporate arts-integrated teaching into school curricula.

\section{RESEARCH AWARDS/ACHIEVEMENTS}

1. Dr. Jody McBrien, Associate Professor, was awarded the Ian Afford (New Zealand) Research Fellowship in Public Policy.

\section{INSTITUTIONAL AWARDS/ACHIEVEMENTS}

1. USFSM was the winner of the "Community Partner of the Year Award," Economic Development Corporation of Sarasota County.

2. Voted "Best Place to Further Your Education" by BIZ(941) magazine of Sarasota, Florida.

3. Winner of the Manatee Chamber of Commerce "Image Manatee Beautification Award." 


\section{Narrative}

\section{Teaching and Learning \\ STRENGTHEN QUALITY AND REPUTATION OF ACADEMIC PROGRAMS AND UNIVERSITIES}

As required by the Florida Legislature in F.S. 1004.34, USF Sarasota-Manatee sought and received separate accreditation in 2011 from the Southern Association of Colleges and Schools Commission on Colleges. Therefore, USF Sarasota-Manatee is in a far-different position in its growth and development as compared to other universities within the State University System of Florida. Whereas most other universities have been in existence for decades or even a century, USF Sarasota-Manatee is an emerging institution, separately accredited just two years ago.

As a result of accepting separate responsibility both fiscally and academically and with approval from the USF Board of Trustees on December 11, 2011, USF Sarasota-Manatee embarked on a new Strategic Plan 2012-16 that directly aligns with the State University System Strategic Plan and the USF System Strategic Plan. USF Sarasota-Manatee takes its mission seriously of providing access to bachelor's and master's degree programs that graduate successful leaders who empower the Suncoast region. USF Sarasota-Manatee states two overarching goals in its Strategic Plan, access and success, in each of the three areas of the SUS Strategic Plan: Teaching \& Learning; Scholarship, Research, \& Innovation; and Public Service \& Community Engagement.

1. ACCESS: Expand access to a university education that benefits students and the local, national, and global community; and (Aligns with USF System Goals 1,2, 3, 4, 5; SUS System Goals 2,3)

2. SUCCESS: Enhance success of student outcomes, faculty productivity, and community impact (Aligns with USF System Goals 1,2,4,5; SUS System Goals 1,2).

\begin{tabular}{|l|l|l|}
\hline \multicolumn{1}{|c|}{ EXPECTATIONS } & \multicolumn{1}{|c|}{ ACCESS } & \multicolumn{1}{|c|}{ SUCCESS } \\
\hline Teaching \& Learning & $\begin{array}{l}\text { 1a. Expand academic programs in distinctive } \\
\text { areas related to the Suncoast's needs and } \\
\text { strengths and across disciplines, when } \\
\text { feasible, including the ability for students to } \\
\text { complete the full four-year bachelor's degree. }\end{array}$ & $\begin{array}{l}\text { 2a. Produce continuous improvement in } \\
\text { student outcome measures, including } \\
\text { retention and graduation rates and student } \\
\text { career results. }\end{array}$ \\
\cline { 3 - 3 } & $\begin{array}{l}\text { 2b. Earn professional accreditation and } \\
\text { recognition, including AACSB and NCATE. }\end{array}$ \\
\hline $\begin{array}{l}\text { Scholarship, Research, \& } \\
\text { Innovation }\end{array}$ & $\begin{array}{l}\text { 1b. Promote innovative scholarship and } \\
\text { community-engaged research. }\end{array}$ & $\begin{array}{l}\text { 2c. Track and promote faculty-developed } \\
\text { measures of scholarship. }\end{array}$ \\
\cline { 2 - 3 } & $\begin{array}{l}\text { 1c. Seek external funding from public grants, } \\
\text { private foundations, and individual donors. }\end{array}$ & 2d. Identify student success predictors. \\
\hline $\begin{array}{l}\text { Public Service \& } \\
\text { Community Engagement }\end{array}$ & $\begin{array}{l}\text { 1d. Partner with a variety of organizations and } \\
\text { stakeholders, including the USF System. }\end{array}$ & $\begin{array}{l}\text { 2e. Earn recognition as a Carnegie } \\
\text { Community-Engaged University. }\end{array}$ \\
\cline { 2 - 3 } & $\begin{array}{l}\text { 1e. Build a university living and learning } \\
\text { community, including residence halls, } \\
\text { academic buildings, and student life facilities. }\end{array}$ & $\begin{array}{l}\text { 2f. Track and share the value of the university's } \\
\text { and graduates' economic and societal } \\
\text { contributions. }\end{array}$ \\
\hline
\end{tabular}

During the 2012-13 academic year, USF Sarasota-Manatee continued the work of pursuing separate professional accreditation for the Colleges of Education and Business through the National Council for 
Accreditation of Teacher Education (NCATE) and the Association to Advance Collegiate Schools of Business (AACSB) respectively. Although currently accredited under USF in Tampa, the Colleges are seeking to assume responsibility and oversight for their own academic quality. Additionally, in 2012-13, the newly named USF Sarasota-Manatee College of Hospitality and Technology Leadership (formerly the School of Hospitality and Restaurant Management) began the application process toward professional accreditation for the B.S. in Hospitality Management from the Accreditation Commission for Programs in Hospitality Administration (ACPHA).

\section{INCREASE DEGREE PRODUCITIVITY AND PROGRAM EFFICIENCY}

Please note, USF Sarasota-Manatee enrolled its first freshman cohort in fall 2013, therefore, many of the traditional FTIC indicators of degree productivity and program efficiency are not yet available.

Degree productivity and program efficiency are at the core of the USF Sarasota-Manatee Strategic Plan. The following measures indicate the USF Sarasota-Manatee's work toward achieving these goals.

USF Sarasota-Manatee continually works to offer academic programs in areas that relate directly to the needs and strengths of the local workforce community by closely working with the county and city Economic Development Corporations and Chambers of Commerce. In 2012-13, USF Sarasota-Manatee sought and received approval to offer the B.A. in Professional and Technical Communications. The interdisciplinary degree program links writing and communication skills with course work in information technology and business operations. USF Sarasota-Manatee also earned approval to offer a master's degree in education that allows students to structure their degree programs to include coursework in a range of concentrations, including online teaching and learning and human resources in partnership with USF Sarasota-Manatee's Master's of Business Administration (MBA).

With its strategic plan's vision, in 2012-13 USF Sarasota-Manatee provided graduating seniors with additional access to bachelor's degrees. According to the Florida Department of Education survey, each year approximately 1,400 graduating high school seniors in this region express interest in attending a public, four-year university in Florida. In the past, most of these students had to leave the area to do so, causing a brain drain, and some were denied the opportunity when other state universities reached freshman enrollment limits. The reputation and quality of the University of South Florida brand attracted more than 400 prospective freshmen to apply to USF Sarasota-Manatee. The faculty selected a highly qualified group from the applicant pool, and the 86-student freshman cohort started its studies in fall of 2013. In contrast to the typical transfer student at USF Sarasota-Manatee, most freshmen attend classes full-time, shortening time-to-degree and debt at graduation.

USF Sarasota-Manatee has an annual fundraiser for scholarships called Brunch on the Bay. Funds from this event complied with the Freshman First Scholarship fundraising drive has enable the USF SarasotaManatee to pay the tuition and fees for all first-year freshman to pay their unmet need. The scholarship will continue through the student's four-year experience as long as they continue to make good progress toward degree and are in good academic standing, and as such these students should graduate debtfree.

USF Sarasota-Manatee expanded its lower-level course offerings in 2012-13, increasing student FTE by 28 percent over 2011-12. It is not expected, however that the lower-level hours will exceed 25percent of 
the total student credit hours. Through the use of tuition differential funding, USF Sarasota-Manatee added or saved 281 course sections.

Tuition differential collections also resulted in 329 students receiving tuition-differential-funded financial awards, totaling more than $\$ 300,000$. At the same time, USF Sarasota-Manatee continued charging the lowest undergraduate tuition rate in the State University System (SUS).

USF Sarasota-Manatee increased the number of degrees awarded at the baccalaureate level by 24 percent when compared to just five years ago. Additionally, in 2012-13, USF Sarasota-Manatee reached an AA transfers 4-year success rate of 79 percent and 2-year success rate of 85 percent.

\section{INCREASE THE NUMBER OF DEGREES AWARDED IN S.T.E.M. AND OTHER PROGRAMS OF STRATEGIC EMPHASIS}

Formerly, as a regional campus, USF Sarasota-Manatee did not have the faculty or facilities to offer any science programs and developed just one technology program. In keeping with its 2012-16 Strategic Plan, USF Sarasota-Manatee made strides in the S.T.E.M. areas in 2012-13 to better serve the local region's needs as summarized below:

\section{B.S. Information Technology}

The number of degrees awarded in Information Technology doubled in 2012-13 in comparison to the prior academic year. This increase is attributed to the faculty and community advisory board reworking degree requirements, streamlining the degree to ensure graduation in a timely manner. Additionally, the work of this group has attracted new students to the major through the development of cutting-edge concentrations in programs such as application development, web design, and I.T. security.

\section{B.S. Biology}

The USF Board of Trustees approved USF Sarasota-Manatee's request to begin offering a B.S. in Biology beginning in the fall of 2014. The course work for this degree will be partially offered on the Mote Marine Laboratory campus and will involve instruction and research mentorship by Mote scientists with doctoral degrees and USF science faculty. To prepare for general education science and this degree, USF Sarasota-Manatee built two student science laboratories on the Mote Marine campus. The cost of the labs was covered by private donations and grants in the amount of $\$ 1.5$ million.

\section{B.S. Communication Sciences \& Disorders}

The first cohort of the B.S. in Communication Sciences \& Disorders graduated during the 2012-13 academic year. USF Sarasota-Manatee was proud to award degrees to 75 aspiring speech language pathologists, prepared to enter into graduate programs in the field. Faculty specifically created this degree program as a second bachelor's degree for students preparing to attend a graduate speech pathology program, having earned their first undergraduate degree in a different field. 


\section{Narrative}

\section{Scholarship, Research and Innovation}

\section{STRENGTHEN QUALITY AND REPUTATION OF SCHOLARSHIP, RESEARCH AND INNOVATION}

Although USF Sarasota-Manatee is an emerging institution, the faculty members highly value their community of scholars and substantive contributions to the body of knowledge in their disciplines. As professors at a regional institution, USF Sarasota-Manatee's faculty members advance theoretical understanding but also apply their scholarship and research within the local community. Faculty members are applying research findings to improve the lives of Sarasota-Manatee community members by leading innovation workshops, hosting national conferences, and partnering with local for-profit and not-for profit organizations to improve their efficiencies, marketing endeavors, and employee skill sets. The following examples highlight the most successful offerings in scholarship, research and innovation:

- Dr. Jean Kabongo, Assistant Professor in the College of Business, offered a workshop for local entrepreneurs to discuss innovation drivers and creativity in the marketplace.

- Dr. Jane Roberts, Chair of the Duvall Family Studies Conference and Instructor in the College of Arts \& Sciences, hosted the biennial conference, Supporting Family Development. The conference, held on the USF Sarasota-Manatee campus, offers a platform for discussion and collaboration of ideas surrounding the issues of family treatment, partner violence, parents in the correctional system, and end-of-life care.

- Dr. Susan Fulton, Assistant Professor in the College of Arts \& Sciences, along with USF Sarasota-Manatee Communication Sciences \& Disorders students and doctoral audiology students from USF in Tampa presented a hands-on workshop for the members of the Hearing Loss Association of Sarasota.

- Dr. Steven Rushton, Associate Professor in the College of Education, hosted the $10^{\text {th }}$ Annual Florida Creativity Weekend on the USF Sarasota-Manatee campus this past spring. More than 40 workshops were offered on creative thinking and problem solving techniques in education, business, technology, government, and the arts.

- Dr. Patricia Hunsader, Assistant Professor in the College of Education, and her student club, USF Sarasota-Manatee Sharing Math $\left(\mathrm{USF}(\mathrm{SM})^{2}\right)$, sponsored an interactive expo for fifth and six graders from all Manatee and Sarasota County schools to highlight the funside of mathematics. The children engaged in hands-on mathematical arts projects to engage their creativity in mathematical contexts.

- Dr. Sunita Lodwig, Instructor in the College of Hospitality \& Technology Leadership, hosted the annual S.T.E.M. Summit for middle school girls. This spring event, held on the USF Sarasota-Manatee campus, offers S.T.E.M.-based workshops to over 200 local, female middle school students. The goal of the summit is to increase both awareness and interest of young females in the S.T.E.M. occupations. 


\section{INCREASE RESEARCH AND COMMERCIALIZATION ACTIVITY}

USF Sarasota-Manatee has made great strides in increasing the number of undergraduate students participating in research. For instance, USF Sarasota-Manatee's first honors program began enrolling students in 2012-13. Students accepted into the program engage in an interdisciplinary curriculum that culminates with an honors seminar and the writing of an honors thesis. The students receive one-on-one mentoring from research faculty who guide them through independent research, thesis writing, and academic presentations.

To recognize the accomplishments of student research, the Student Research Symposium is held each fall semester. The Symposium provides USF Sarasota-Manatee students an opportunity to present their work, learn from peers, and network with USF Sarasota-Manatee faculty. From the Symposium, four students are nominated to the National Conference for Undergraduate Research (NCUR). Travel awards are granted to cover the students' costs.

\section{INCREASE COLLABORATION AND EXTERNAL SUPPORT FOR RESEARCH ACTIVITY}

As a regional university, USF Sarasota-Manatee offers its faculty and staff multiple opportunities to partner within the community.

In August 2012, the faculty in the College of Education established the Center for Partnerships for Arts Integration in Teaching (PAInT). The mission of the new center is to create a network of artists, teachers, and professors who collaborate to integrate the arts in teacher preparation and in schools. Both Sarasota and Bradenton are well known nationally and internationally for their preponderance of arts organizations and venues. The PAInT Center now provides a visible link from USF Sarasota-Manatee to the local arts community. For instance, the center received a grant from the Manatee Community Foundation's Leslie and Margaret Weller Fund to support collaboration between the Manatee County school district and USF Sarasota-Manatee College of Education to pilot an arts-integrated program titled "Collaboration, Arts Integration, and the Common Core." Through this collaboration, Manatee County teachers from Title 1 schools pair with select USF Sarasota-Manatee interns and a teaching artist from the Center to develop innovative teaching curricula and strategies based on the Common Core Standards.

Through a partnership with Mote Marine Laboratories, USF Sarasota-Manatee will soon offer the only B.S. in Biology degree in the Sarasota-Manatee area. The partnership with Mote is a collaborative effort that will join USF Sarasota-Manatee science faculty and students with Mote scientists to conduct research across a variety of scientific fields, thus enriching student learning outcomes. Through the collaboration, the partners plan to bring additional marine research funding to the area as well as inspire the next generation of biologists, doctors, and science professionals. 


\section{Narrative}

\section{Community and Business Engagement STRENGTHEN QUALITY AND REPUTATION OF COMMITMENT TO COMMUNITY AND BUSINESS ENGAGEMENT}

To reach its envisioned future, USF Sarasota-Manatee strategically prioritizes collaborative work with local businesses, governments, and institutions. For example, USF Sarasota-Manatee accepted an offer to become a member of the Manatee Sarasota Workforce Leadership Team. Convened by the CareerEdge Funders Collaborative, the Manatee Sarasota Workforce Leadership Team represents collaboration between the Economic Development Corporations of Manatee and Sarasota Counties, the Manatee and Sarasota Chambers of Commerce, Gulf Coast Community Foundation, State College of Florida, Suncoast Workforce Board, Sarasota-Manatee Resources Association, and USF SarasotaManatee. The team has been working since 2012 to identify skill gaps and other workforce issues and to find collaborative and coordinated solutions to help to strengthen organizational commitment to local employers.

\section{INCREASE LEVELS OF COMMUNITY AND BUSINESS ENGAGEMENT}

USF Sarasota-Manatee has had a strong presence and reputation for quality in the City of North Port since opening the USF Sarasota-Manatee at North Port Instructional Site in 2010. In 2012-13, USF Sarasota-Manatee worked to expand the commitment to the City by arranging a memorandum of understanding with the Small Business Development Center of Florida (SDBC). The agreement provides space to the non-profit organization at the North Port site as a means of connecting the entrepreneurs of southern Sarasota County with the consulting services and resources of the Center. The SDBC, which works in connection with USF in Tampa, will also use the space to conduct workshops for local businesses.

In another example of business engagement, the USF Sarasota-Manatee College of Hospitality \& Technology Leadership partnered with M3 Accounting, a national leader in hotel accounting software, to create virtual training environments that represent real-world hotel management scenarios. Hotel owners, operators, and managers at more than 3,000 properties throughout North America currently use M3's web-based software to improve data-based decision making. 


\section{INCREASE COMMUNITY AND BUSINESS WORKFORCE}

USF Sarasota-Manatee is proud to provide educational opportunities to the Sarasota-Manatee region that permit students to "learn where they earn." In 2012-13, USF Sarasota-Manatee conferred 25 percent more undergraduate degrees than it did just five years ago. According to the most recent Federal Education \& Training Placement Information Program (FETPIP) data, 75 percent of graduates who earn a USF Sarasota-Manatee bachelor's degree are employed. According to FETPIP summary data, this placement rate was higher than the reported placement rates of the other SUS institutions (http://www.fldoe.org/fetpip/pdf/1011pdf/sus1011b.pdf). The estimated full-quarter wages of these fall 2011 USF Sarasota-Manatee graduates was fourth highest amongst SUS institutions. 


\section{Data Tables}

\section{FINANCIAL RESOURCES}

Table 1A. Education and General Revenues

Table 1B. Education and General Expenditures

Table 1C. Funding per Student FTE

Table 1D. Other Budget Entities

Table 1E. Voluntary Support of Higher Education

Table 1F. Tuition Differential Fee

PERSONNEL

Table 2A. Personnel Headcount

\section{ENROLLMENT}

Table 3A. Full-time Equivalent (FTE) Enrollment

Table 3C. Enrollment by Method of Instruction

\section{UNDERGRADUATE EDUCATION}

Table 4A. Baccalaureate Degree Program Changes in AY 2011-2012

Table 4B. Retention Rates

Table 4C. Full-time, First-Time-in-College (FTIC) Six-Year Graduation Rates

Table 4D. Full- and Part-time FTIC Graduation Rates

Table 4E. AA Transfers Graduation Rates

Table 4F. Other Transfers Graduation Rates

Table 4G. Baccalaureate Degrees Awarded

Table 4H. Baccalaureate Degrees Awarded in Areas of Strategic Emphasis

Table 4I. Baccalaureate Degrees Awarded to Underrepresented Groups

Table 4J. Baccalaureate Degrees Without Excess Credit Hours

Table 4K. Undergraduate Course Offerings

Table 4L. Faculty Teaching Undergraduates

Table 4M. Student/Faculty Ratio

Table 4N. Licensure/Certification Exam: Nursing (NCLEX)

\section{GRADUATE EDUCATION}

Table 5A. Graduate Degree Program Changes in AY 2011-2012

Table 5B. Graduate Degrees Awarded

Table 5C. Graduate Degrees Awarded in Areas of Strategic Emphasis

Table 5D. Licensure/Certification Exams for Graduate Programs

\section{RESEARCH \& ECONOMIC DEVELOPMENT}

Table 6A. Research and Development Expenditures

Table 6B. Centers of Excellence 


\section{Section 1 - Financial Resources}

\section{TABLE 1A. University Education and General Revenues}

\begin{tabular}{lrrrrr} 
& $\begin{array}{c}\mathbf{2 0 0 9 - 1 0} \\
\text { Actual }\end{array}$ & $\begin{array}{c}\mathbf{2 0 1 0 - 1 1} \\
\text { Actual }\end{array}$ & $\begin{array}{c}\mathbf{2 0 1 1 - 1 2} \\
\text { Actual }\end{array}$ & $\begin{array}{c}\mathbf{2 0 1 2 - 1 3} \\
\text { Actual }\end{array}$ & $\begin{array}{c}\mathbf{2 0 1 3 - 1 4} \\
\text { Estimates }\end{array}$ \\
\hline MAIN OPERATIONS & & & & & \\
\hline Recurring State Funds & $\$ 11,996,133$ & $\$ 11,882,443$ & $\$ 11,296,196$ & $\$ 11,109,190$ & $\$ 12,192,740$ \\
\hline Non-Recurring State Funds & $\$ 85,400$ & $\$ 93,391$ & $\$ 123,086$ & $-\$ 993,867$ & $\$ 882,604$ \\
\hline Tuition & $\$ 5,234,584$ & $\$ 5,766,517$ & $\$ 5,991,659$ & $\$ 6,082,277$ & $\$ 7,397,841$ \\
\hline Tuition Differential Fee & $\$ 193,210$ & $\$ 498,603$ & $\$ 847,655$ & $\$ 1,397,116$ & $\$ 1,505,543$ \\
\hline Misc. Fees \& Fines & $\$ 66,227$ & $\$ 69,897$ & $\$ 63,259$ & $\$ 61,389$ & $\$ 96,253$ \\
\hline Phosphate Research TF & $\$ 0$ & $\$ 0$ & $\$ 0$ & $\$ 0$ & $\$ 0$ \\
\hline Federal Stimulus Funds & $\$ 1,012,126$ & $\$ 968,456$ & $\$ 0$ & $\$ 0$ & $\$ 0$ \\
\hline SUBTOTAL & $\$ 18,587,680$ & $\$ 19,279,307$ & $\$ 18,321,855$ & $\$ 17,656,105$ & $\$ \mathbf{2 2 , 0 7 4 , 9 8 1}$
\end{tabular}

HEALTH SCIENCE CENTER / MEDICAL SCHOOL SUBTOTAL $\$ 0 \quad \$ 0$ $\$ 0$ $\$ 0$ $\$ 0$ TOTAL $\begin{array}{lllll}\$ 18,587,680 & \$ 19,279,307 & \$ 18,321,855 & \$ 17,656,105 & \$ 22,074,981\end{array}$

Recurring State Funds: State recurring funds include general revenue and lottery education \& general (E\&G) appropriations and any administered funds provided by the state, including annual adjustments of risk management insurance premiums for the estimated year. This does not include technical adjustments or transfers made by universities after the appropriation. Please note: for estimated 2012-13 this figure includes the non-recurring $\$ 300 \mathrm{M}$ system budget reduction. - Source: For actual years, SUS Final Amendment Packages; for estimated year the 2012-13 Allocation Summary and Workpapers (Total E\&G general revenue \& lottery minus non-recurring) and Board of Governors staff calculations for risk management insurance adjustments. Non-Recurring State Funds: State non-recurring funds include general revenue and lottery education \& general appropriations and any administered funds provided by the state. This does not include technical adjustments or transfers made by Universities after the appropriation - Source: non-recurring appropriations section of the annual Allocation Summary and Workpapers document and all other non-recurring budget amendments allocated later in the fiscal year. Tuition: Actual resident \& nonresident tuition revenues collected from students, net of fee waivers. - Source: Operating Budget, Report 625 - Schedule I-A. Tuition Differential Fee: Actual tuition differential revenues collected from undergraduate students - Source: Operating Budget, Report 625 - Schedule I-A. Miscellaneous Fees \& Fines: Other revenue collections include items such as application fees, late registration fees, library fines, miscellaneous revenues. This is the total revenue from Report 625 minus tuition and tuition differential fee revenues. This does not include local fees - Source: Operating Budget, Report 625 - Schedule I-A. Phosphate Research Trust Fund: State appropriation for the Florida Industrial and Phosphate Research Institute at the University of South Florida (for history years through 2011-12); beginning 2012-13 the Phosphate Research Trust Fund is appropriated through Florida Polytechnic University. Other Operating Trust Funds- For UF-IFAS and UF-HSC, actual revenues from the Incidental Trust Funds and Operations \& Maintenance Trust Fund are provided by the University of Florida. Source: Final Amendment Package. Federal Stimulus Funds: Non-recurring American Recovery and Reinvestment Act funds appropriated by the state Source: SUS Final Amendment Package. 
Section 1 - Financial Resources (continued) TABLE 1B. University Education and General Expenditures

\begin{tabular}{lrrrrr} 
& $\begin{array}{c}\mathbf{2 0 0 9 - 1 0} \\
\text { Actual }\end{array}$ & $\begin{array}{c}\mathbf{2 0 1 0 - 1 1} \\
\text { Actual }\end{array}$ & $\begin{array}{c}\mathbf{2 0 1 1 - 1 2} \\
\text { Actual }\end{array}$ & $\begin{array}{c}\mathbf{2 0 1 2 - 1 3} \\
\text { Actual }^{*}\end{array}$ & $\begin{array}{c}\mathbf{2 0 1 3 - 1 4} \\
\text { Estimates }^{* *}\end{array}$ \\
\hline MAIN OPERATIONS & & & & & \\
\hline Instruction/Research & $\$ 9,786,291$ & $\$ 9,995,147$ & $\$ 9,923,115$ & $\$ 11,126,815$ & $\$ 15,496,808$ \\
\hline Administration and Support & $\$ 2,528,316$ & $\$ 2,526,918$ & $\$ 2,196,199$ & $\$ 3,241,240$ & $\$ 2,803,452$ \\
\hline PO\&M & $\$ 920,903$ & $\$ 1,331,348$ & $\$ 1,135,491$ & $\$ 1,071,460$ & $\$ 1,111,873$ \\
\hline Student Services & $\$ 1,829,151$ & $\$ 1,859,587$ & $\$ 1,848,275$ & $\$ 1,582,753$ & $\$ 1,445,766$ \\
\hline Library/Audio Visual & $\$ 1,191,766$ & $\$ 363,719$ & $\$ 1,071,269$ & $\$ 1,102,445$ & $\$ 1,217,082$ \\
\hline Other & $\$ 0$ & $\$ 0$ & $\$ 0$ & $\$ 0$ & $\$ 0$ \\
\hline TOTAL & $\$ 16,256,427$ & $\$ 16,076,719$ & $\$ 16,174,349$ & $\$ 18,124,713$ & $\$ \mathbf{2 2 , 0 7 4 , 9 8 1}$
\end{tabular}

HEALTH SCIENCE CENTER / MEDICAL SCHOOL TOTAL $\$ 0$ $\$ 0$ $\$ 0$ \$0

TOTAL

\section{$\$ \$ 16,256,427 \quad \$ 16,076,719 \quad \$ 16,174,349 \quad \$ 18,124,713 \quad \$ 22,074,981$}

The table reports the actual and estimated amount of expenditures from revenues appropriated by the legislature for each fiscal year. The expenditures are classified by Program Component (i.e., Instruction/Research, PO\&M, Administration, etc...) for activities directly related to instruction, research and public service. The table does not include expenditures classified as non-operating expenditures (i.e., to service assetrelated debts), and therefore excludes a small portion of the amount appropriated each year by the legislature. Note*: FY 2012-2013 reflects a change in reporting expenditures from prior years due to the new carry-forward reporting requirement as reflected in the 2013-2014 SUS Operating Budget Reports. Since these expenditures will now include carry-forward expenditures, these data are no longer comparable to the current-year revenues reported in table 1A, or prior year expenditures in table 1B. Note**: Estimated year amounts are from FY 2013-14 appropriations only and do not include anticipated expenditures from university carry-forward funds.

Instruction \& Research: Includes expenditures for state services related to the instructional delivery system for advanced and professional education. Includes functions such as; all activities related to credit instruction that may be applied toward a postsecondary degree or certificate; nonproject research and service performed to maintain professional effectives; individual or project research; academic computing support; academic source or curriculum development. Source: Operating Budget Summary - Expenditures by Program Activity (or Report 645). Administration \& Support Services: Expenditures related to the executive direction and leadership for university operations and those internal management services which assist and support the delivery of academic programs. Source: Operating Budget Summary - Expenditures by Program Activity (or Report 645). PO\&M: Plant Operations \& Maintenance expenditures related to the cleaning and maintenance of existing grounds, the providing of utility services, and the planning and design of future plant expansion and modification. Student Services: Includes resources related to physical, psychological, and social well being of the student. Includes student service administration, social and cultural development, counseling and career guidance, financial aid, and student admissions and records. Other: includes Institutes and Research Centers, Radio/TV, Museums and Galleries, Intercollegiate Athletics, Academic Infrastructure Support Organizations. Source: Operating Budget Summary - Expenditures by Program Activity (or Report 645). 


\section{Section 1 - Financial Resources (continued)}

\section{TABLE 1C. State Funding per Full-Time Equivalent (FTE) Student}

(Data provided by USF)

\begin{tabular}{lrrrrr} 
& $\begin{array}{c}\mathbf{2 0 0 8 - 0 9} \\
\text { Actual }\end{array}$ & $\begin{array}{r}\mathbf{2 0 0 9 - 1 0} \\
\text { Actual }\end{array}$ & $\begin{array}{r}\mathbf{2 0 1 0 - 1 1} \\
\text { Actual }\end{array}$ & $\begin{array}{r}\mathbf{2 0 1 1 - 1 2} \\
\text { Actual }\end{array}$ & $\begin{array}{r}\mathbf{2 0 1 2 - 1 3} \\
\text { Actual }\end{array}$ \\
\hline Appropriated Funding per FTE & & & & & \\
\hline$\quad$ General Revenue & $\$ 8,813$ & $\$ 7,130$ & $\$ 6,840$ & $\$ 6,380$ & $\$ 5,827$ \\
$\quad$ Lottery Funds & $\$ 693$ & $\$ 546$ & $\$ 659$ & $\$ 752$ & $\$ 571$ \\
$\quad \begin{array}{l}\text { Tuition \& Fees } \\
\text { Other Trust Funds }\end{array}$ & $\$ 3,228$ & $\$ 3,490$ & $\$ 4,374$ & $\$ 4,548$ & $\$ 5,122$ \\
$\quad$ TOTAL & $\$ 0$ & $\$ 643$ & $\$ 606$ & $\$ 0$ & $\$ 0$ \\
Actual Funding per FTE & $\$ 12,734$ & $\$ 11,809$ & $\$ 12,480$ & $\$ 11,681$ & $\$ 11,520$ \\
\hline Tuition \& Fees & & & & & \\
$\quad$ TOTAL & $\$ 3,228$ & $\$ 3,490$ & $\$ 3,923$ & $\$ 4,311$ & $\$ 4,770$ \\
\end{tabular}

Notes: (1) FTE is based on actual FTE, not funded FTE; (2) does not include Health-Science Center funds or FTE; (3) FTE for these metrics uses the standard IPEDS definition of FTE, equal to 30 credit hours for undergraduates and 24 for graduates; and (4) actual funding per student is based on actual tuition and E\&G fees (does not include local fees) collected. Sources: Appropriated totals from the annual Final Amendment Package data. Estimated year data from the Allocation Summary document. Actual Student Fees from the Operating Budget 625 reports. This does not include appropriations for special units (i.e., IFAS, Health Science Centers, and Medical Schools). Tuition and fee revenues include tuition and tuition differential fee and E\&G fees (i.e., application, late registration, and library fees/fines). Other local fees that do not support E\&G activities are not included here (see Board of Governors Regulation 7.003). This data is not adjusted for inflation.

TABLE 1D. University Other Budget Entities

$\begin{array}{cc}2009-10 & 2010-11 \\ \text { Actual } & \text { Actual }\end{array}$

2011-12 Actual
2012-13 Actual
2013-14 Estimates

\section{Auxiliary Enterprises}

Revenues

Expenditures

\section{Previously reported only}

at the USF System level.

$\$ 1,888,702$

$\$ 1,452,865$
$\$ 1,859,520$
$\$ 1,144,646$

$\$ 1,980,802$

$\$ 1,567,145$

\section{Contracts \& Grants}

Revenues

Expenditures

\section{Local Funds}

\section{Revenues}

Expenditures

\section{Previously reported only}

at the USF System level.

$\$ 207,283$
$\$ 300,044$

$\$ 38,107$

$\$ 152,204$
$\$ 375,000$

$\$ 399,218$

\section{Faculty Practice Plans}

Revenues
Expenditures
Previously reported only

at the USF System level.

$\$ 1,149,499$
$\$ 576,226$

$\$ 1,149,481$
$\$ 1,060,747$

$\$ 1,205,321$

$\$ 1,222,772$

$\begin{array}{llll}\text { Previously reported only } & \$ 0 & \$ 0 & \$ 0 \\ \text { at the USF System level. } & \$ 0 & \$ 0 & \$ 0\end{array}$

Notes: Revenues do not include transfers. Expenditures do not include non-operating expenditures. Auxiliary Enterprises are self supported through fees, payments and charges. Examples include housing, food services, bookstores, parking services, health centers. Contract \& Grants resources are received from federal, state or private sources for the purposes of conducting research and public service activities. Local Funds are associated with student activity (supported by the student activity fee), student financial aid, concessions, intercollegiate athletics, technology fee, green fee, and student life \& services fee. Faculty Practice Plan revenues/receipts are funds generated from faculty practice plan activities. Faculty Practice Plan expenditures include all expenditures relating to the faculty practice plans, including transfers between other funds and/or entities. This may result in double counting in information presented within the annual report. Source: Operating Budget, Report 615. 


\section{Section 1 - Financial Resources (continued)}

\section{TABLE 1E. Voluntary Support of Higher Education}

\begin{tabular}{cccccc} 
& $2007-08$ & $2008-09$ & $2009-10$ & $2010-11$ & $2011-12$ \\
\hline $\begin{array}{c}\text { Endowment Value } \\
(\$ 1000 \text { s })\end{array}$ & & & & \\
\hline $\begin{array}{c}\text { Gifts Received } \\
(\$ 1000 \text { s })\end{array}$ & & This data is only available for the USF System. & \\
\hline $\begin{array}{c}\text { Percentage of } \\
\text { Alumni Donors }\end{array}$ & & & & \\
\hline
\end{tabular}

Notes: Endowment value at the end of the fiscal year, as reported in the annual NACUBO Endowment Study. Gifts Received as reported in the Council for Aid to Education's Voluntary Support of Education (VSE) survey in the section entitled "Gift Income Summary," this is the sum of the present value of all gifts (including outright and deferred gifts) received for any purpose and from all sources during the fiscal year, excluding pledges and bequests. (There's a deferred gift calculator at www.cae.org/vse.) The present value of non-cash gifts is defined as the tax deduction to the donor as allowed by the IRS. Percentage of Alumni Donors as reported in the Council for Aid to Education's Voluntary Support of Education (VSE) survey in the section entitled "Additional Details," this is the number of alumni donors divided by the total number of alumni, as of the end of the fiscal year. "Alumni," as defined in this survey, include those holding a degree from the institution as well as those who attended the institution but did not earn a degree.

\section{TABLE 1F. Tuition Differential Fees (TDF)}

\begin{tabular}{lccc} 
& $\mathbf{2 0 1 0 - 1 1}$ & $\mathbf{2 0 1 1 - 1 2}$ & $\mathbf{2 0 1 2 - 1 3}$ \\
\hline TDF Revenues Generated & $\$ 498,603$ & $\$ 847,655$ & $\$ 1,397,116$ \\
\hline Students Receiving TDF Funded Award & 188 & 254 & 329 \\
Total Value of TDF Funded Financial Aid Awards & $\$ 796$ & $\$ 1,002$ & $\$ 967$
\end{tabular}

\section{Florida Student Assistance Grant (FSAG) Eligible Students}

\begin{tabular}{lccc}
\hline Number of Eligible Students & 380 & 551 & 592 \\
Number Receiving a TDF Waiver & 0 & 0 & 0 \\
Value of TDF Waivers & $\$ 0$ & $\$ 0$ & $\$ 0$
\end{tabular}

Note: TDF Revenues Generated refers to actual tuition differential revenues collected from undergraduate students as reported on the Operating Budget, Report 625 - Schedule I-A. Students Receiving TDF Funded Award reports the number of unduplicated students who have received a financial aid award that was funded by tuition differential revenues. Value of TDF Funded Award refers to the average value of financial aid awards funded by the the Tuition Differential Fee funds. Florida Student Assistance Grant (FSAG) Eligible Students: Number of Eligible Students refers to total annual unduplicated count of undergraduates at the institution who are eligible for FSAG in the academic year, whether or not they received FSAG awards. Number Receiving a TDF Waiver refers to annual unduplicated count of FSAG-eligible students receiving a waiver, partial or full, of the tuition differential fees at the institution during the academic year, regardless of the reason for the waiver. Value of TDF Waivers refers to the average value of waivers provided to FSAG-eligible undergraduates at the institution during the academic year, regardless of the reason for the waiver. 


\section{Section 2 - Personnel}

\section{TABLE 2A. Personnel Headcount (in Fall term only)}

\begin{tabular}{lccccc} 
& $\mathbf{2 0 0 8}$ & $\mathbf{2 0 0 9}$ & $\mathbf{2 0 1 0}$ & $\mathbf{2 0 1 1}$ & $\mathbf{2 0 1 2}$ \\
\hline Full-time Employees & & & & & \\
\hline Tenured Faculty & 10 & 11 & 13 & 13 & 14 \\
Tenure-track Faculty & 18 & 20 & 19 & 24 & 21 \\
Non-Tenure Track Faculty & 22 & 21 & 17 & 20 & 22 \\
Instructors Without Faculty Status & 0 & 0 & 0 & 0 & 0 \\
Graduate Assistants/Associates & 0 & 0 & 0 & 0 & 0 \\
Non-Instructional Employees & 99 & 99 & 101 & 95 & 93 \\
FULL-TIME SUBTOTAL & $\mathbf{1 4 9}$ & $\mathbf{1 5 1}$ & $\mathbf{1 5 0}$ & $\mathbf{1 5 2}$ & $\mathbf{1 5 0}$
\end{tabular}

\section{Part-time Employees}

Tenured Faculty

Tenure-track Faculty

Non-Tenure Track Faculty

Instructors Without Faculty Status

Graduate Assistants/Associates

Non-Instructional Employees

Status

PART-TIME SUBTOTAL
$12-5-2013$

\footnotetext{
TOTAL

\section{5}

Note: This table is based on the annual IPEDS Human Resources Survey, and provides full- and part-time medical and non-medical staff by faculty status and primary function/occupational activity. Tenured and Tenure-Track Faculty include those categorized within instruction, research, or public service. Non-Tenure Track Faculty includes adjunct faculty (on annual and less than annual contracts) and faculty on multi-year contracts categorized within instruction, research, or public service. Instructors Without Faculty Status includes postdoctoral research associates, and individuals hired as a staff member primarily to do research on a 3-year contract without tenure eligibility categorized within instruction, research, or public service. Non-Instructional Employees includes all executive, administrative and managerial positions regardless of faculty status; as well as, other support and service positions regardless of faculty status. Note: The universities vary on how they classify adjuncts (some include them as non-tenure track faculty while others do not consider them faculty and report them as instructors without faculty status) and part-time non-instructional employees.
}

16

1
0
8
0
5
2
16

$16 \quad 8$

1

1
0

$4 \quad 86$

$86 \quad 75 \quad 64$

$0 \quad 0$

2

4

10

0

0

91

5 


\section{Section 3 - Enrollment}

\section{TABLE 3A. Full-Time Equivalent (FTE) Enrollment}

\begin{tabular}{|c|c|c|c|c|c|c|}
\hline & \multicolumn{2}{|c|}{ 2010-11 } & \multicolumn{2}{|c|}{ 2011-12 } & \multicolumn{2}{|c|}{ 2012-13 } \\
\hline & $\begin{array}{l}\text { State- } \\
\text { Funded }\end{array}$ & Actual & $\begin{array}{l}\text { State- } \\
\text { Funded }\end{array}$ & Actual & $\begin{array}{l}\text { State- } \\
\text { Funded }\end{array}$ & Actual \\
\hline \multicolumn{7}{|c|}{ FLORIDA RESIDENTS } \\
\hline LOWER-DIVISION & 0 & 64 & 0 & 107 & 0 & 133 \\
\hline UPPER-DIVISION & 798 & 984 & 798 & 959 & 798 & 928 \\
\hline MASTER'S (GRAD I) & 182 & 123 & 182 & 105 & 182 & 92 \\
\hline DOCTORAL (GRAD II) & 0 & 2 & 0 & 0 & 0 & 0 \\
\hline TOTAL & 980 & 1,173 & 980 & 1,171 & 980 & 1,153 \\
\hline
\end{tabular}

\section{NON-FLORIDA RESIDENTS}

\begin{tabular}{lcc|cc|cc}
\hline LOWER-DIVISION & $\cdot$ & 2 & $\cdot$ & 3 & $\cdot$ & 8 \\
UPPER-DIVISION & $\cdot$ & 21 & $\cdot$ & 21 & $\cdot$ & 19 \\
MASTER'S (GRAD I) & $\cdot$ & 2 & $\cdot$ & 6 & $\cdot$ & 6 \\
DOCTORAL (GRAD II) & $\cdot$ & 0 & $\cdot$ & 0 &. & 0 \\
\hline TOTAL & $\mathbf{0}$ & $\mathbf{2 5}$ & $\mathbf{0}$ & $\mathbf{3 0}$ & $\mathbf{0}$ & $\mathbf{3 3}$
\end{tabular}

TOTAL FTE

\begin{tabular}{|c|c|c|c|c|c|c|}
\hline LOWER-DIVISION & 0 & 66 & 0 & 110 & 0 & 141 \\
\hline UPPER-DIVISION & 798 & 1,005 & 798 & 980 & 798 & 947 \\
\hline MASTER'S (GRAD I) & 182 & 125 & 182 & 111 & 182 & 97 \\
\hline DOCTORAL (GRAD II) & 0 & 2 & 0 & 0 & 0 & 0 \\
\hline TOTAL & 980 & 1,198 & 980 & 1,201 & 980 & 1,186 \\
\hline $\begin{array}{l}\text { TOTAL } \\
\text { US Definition }\end{array}$ & 1,307 & 1,597 & 1,307 & 1,601 & 1,307 & 1,581 \\
\hline
\end{tabular}

Notes: Full-time Equivalent (FTE) student is a measure of instructional effort (and student activity) that is based on the number of credit hours that students enroll. FTE is based on the Florida definition, which divides undergraduate credit hours by 40 and graduate credit hours by 32 (US definition based on Undergraduate FTE $=30$ and Graduate FTE = 24 credit hours). Funded enrollment as reported in the General Appropriations Act and set by the legislature. Actual enrollment only reports 'state-fundable' FTE as reported by Universities to the Board of Governors in the Student Instruction File (SIF). Totals are actual and may not equal sum of reported student levels due to rounding of student level FTE. 


\section{Section 3 - Enrollment (continued)}

\section{TABLE 3C. Full-Time Equivalent (FTE) Enrollment by Method of Instruction}

2010-11

2011-12

2012-13

TRADITIONAL

LOWER-DIVISION

UPPER-DIVISION

MASTER'S (GRAD I)

DOCTORAL (GRAD II)

TOTAL
41

536

100

0

678
63

503

86

1

653
65

459

72

0

597

\section{HYBRID}

$\begin{array}{lccc}\text { LOWER-DIVISION } & 0 & 3 & 7 \\ \text { UPPER-DIVISION } & 27 & 31 & 26 \\ \text { MASTER'S (GRAD I) } & 3 & 4 & 4 \\ \text { DOCTORAL (GRAD II) } & 0 & 0 & 0 \\ \text { TOTAL } & 30 & 37 & 37\end{array}$

DISTANCE LEARNING

$\begin{array}{lccc}\text { LOWER-DIVISION } & 25 & 44 & 69 \\ \text { UPPER-DIVISION } & 442 & 446 & 465 \\ \text { MASTER'S (GRAD I) } & 22 & 20 & 22 \\ \text { DOCTORAL (GRAD II) } & 1 & 0 & 0 \\ \text { TOTAL } & \mathbf{4 9 1} & \mathbf{5 1 0} & \mathbf{5 5 5}\end{array}$

\section{TOTAL}

LOWER-DIVISION
UPPER-DIVISION
MASTER'S (GRAD I)
DOCTORAL (GRAD II)
TOTAL

LOWER-DIVISION

UPPER-DIVISION

\section{6}

1,005

125

1

1,198

\section{0}

980

110

1

1,201
141

950

97

0

Note: Full-time Equivalent (FTE) student is a measure of instructional effort (and student activity) that is based on the number of credit hours that students enroll. FTE is based on the Florida definition, which divides undergraduate credit hours by 40 and graduate credit hours by 32 . Distance Learning is a course in which at least 80 percent of the direct instruction of the course is delivered using some form of technology when the student and instructor are separated by time or space, or both (per 1009.24(17), F.S.). Hybrid is a course where $50 \%$ to $79 \%$ of the instruction is delivered using some form of technology, when the student and instructor are separated by time or space, or both (per SUDS data element 2052). Traditional (and Technology Enhanced) refers to primarily face to face instruction utilizing some form of technology for delivery of supplemental course materials for no more than $49 \%$ of instruction (per SUDS data element 2052). Totals are actual and may not equal sum of reported student levels due to rounding of student level FTE. Total FTE are equal in tables 3A, 3B. 


\section{Section 4 - Undergraduate Education}

\section{TABLE 4A. Baccalaureate Degree Program Changes in AY 2012-13}

\begin{tabular}{|c|c|c|c|c|c|}
\hline Title of Program & $\begin{array}{c}\text { Six-digit } \\
\text { CIP } \\
\text { Code }\end{array}$ & $\begin{array}{l}\text { Degree } \\
\text { Level }\end{array}$ & $\begin{array}{l}\text { Date of } \\
\text { UBOT } \\
\text { Action }\end{array}$ & $\begin{array}{l}\text { Starting } \\
\text { or Ending } \\
\text { Term }\end{array}$ & Comments \\
\hline \multicolumn{6}{|l|}{ New Programs } \\
\hline $\begin{array}{l}\text { Professional and Technical } \\
\text { Communication }\end{array}$ & 23.1303 & B & $12 / 13 / 2012$ & Fall 2013 & \\
\hline \multicolumn{6}{|l|}{ Terminated Programs } \\
\hline \multicolumn{6}{|l|}{ None } \\
\hline \multicolumn{6}{|l|}{ Inactive Programs } \\
\hline None & & & & & \\
\hline & & & & & \\
\hline \multicolumn{6}{|c|}{ New Programs Considered By University But Not Approved } \\
\hline None & & & & & \\
\hline
\end{tabular}

Note: This table does not include new majors or concentrations added under an existing degree program CIP Code. This table reports the new and terminated program changes based on Board action dates between May 5, 2012 and May 4, 2013.

New Programs are proposed new degree programs that have been completely through the approval process at the university and, if appropriate, the Board of Governors. Does not include new majors or concentrations added under an existing degree program CIP Code.

Terminated Programs are degree programs for which the entire CIP Code has been terminated and removed from the university's inventory of degree programs. Does not include majors or concentrations terminated under an existing degree program CIP Code if the code is to remain active on the academic degree inventory.

Inactive Programs are degree programs for which enrollments have been temporarily suspended for the entire CIP Code, but the program CIP Code has not been terminated. Does not include majors or concentrations suspended under an existing degree program CIP Code if the code is to remain active on the academic degree inventory and new enrollments in any active major will be reported.

New Programs Considered by University But Not Approved includes any programs considered by the university board of trustees, or any committee of the board, but not approved for implementation. Also include any programs that were returned prior to board consideration by the university administration for additional development, significant revisions, or re-conceptualization; regardless of whether the proposal was eventually taken to the university board for approval. Count the returns once per program, not multiple times the proposal was returned for revisions, unless there is a total re-conceptualization that brings forward a substantially different program in a different CIP Code. 


\section{Section 4 - Undergraduate Education (continued)}

\section{TABLE 4B. Full-time, First-Time-in-College (FTIC) Retention Rates Retained in the Second Fall Term at Same University}

2008-09

2009-10

2010-11

2008-09 2009-10 2010-11 2011-12 Preliminary
Cohort Size
\% Retained
\% Retained
with GPA of 2.0 or higher
USF-SM began admitting FTICs in Fall 2013.
Notes: Cohorts are based on undergraduate students who enter the institution in the Fall term (or Summer term and continue into the Fall term). Percent
Retained is based on student enrollment in the Fall term following their first year. Percent Retained with GPA Above 2.0 is based on student enrollment
in the Fall term following their first years for those students with a GPA of 2.0 or higher at the end of their first year (Fall,, Spring, Summer). The most
recent year of Retention data is based on preliminary data (SIFP file) that is comparable to the final data (SIF file) but may be revised in the following years
based on changes in student cohorts.

\section{TABLE 4C. Full-time, First-Time-in-College (FTIC) Six-Year Graduation Rates}

Term of Entry
2003-09 2004-10 2005-11 2006-12

2007-13 Preliminary

\section{Cohort Size}

\section{$\%$ Graduated}

\section{\% Still Enrolled}

\section{USF-SM began admitting FTICs in Fall 2013.}

\section{$\%$ Success Rate}

Notes: Cohorts are based on undergraduate students who enter the institution in the Fall term (or Summer term and continue into the Fall term). Percent Graduated is based on federal rate and does not include students who originally enroll as part-time students, or who transfer into the institution. This metric complies with the requirements of the federal Student Right to Know Act that requires institutions to report the completion status at $150 \%$ of normal time (or six years). Success Rate measures the percentage of an initial cohort of students who have either graduated or are still enrolled at the same university. Since degrees can be awarded after the last semester of coursework, the most recent year of data in this table provides preliminary data that may change with the addition of "late degrees". Late degrees reported in conjunction with the IPEDS Graduation Rate Survey due in mid-April will be reflected in the following year. 


\section{Section 4 - Undergraduate Education (continued)}

TABLE 4D. FTIC Progression and Graduation Rates (includes Full- and Part-time students)

\section{4 - Year Rates}

2005-09

2006-10

2007-11

Cohort

\section{From Same University}

$\%$ Graduated

\% Still Enrolled

USF-SM began admitting FTICs in Fall 2013.

\section{From Other SUS University}

$\%$ Graduated

$\%$ Still Enrolled

USF-SM began admitting FTICs in Fall 2013.

\section{From State University System}

$\%$ Graduated

\% Still Enrolled

USF-SM began admitting FTICs in Fall 2013.

$\%$ Success Rate

6 - Year Rates

2003-09 2004-10

2005-11

Cohort

From Same University

$\%$ Graduated

$\%$ Still Enrolled

USF-SM began admitting FTICs in Fall 2013.

From Other SUS University

$\%$ Graduated

$\%$ Still Enrolled

USF-SM began admitting FTICs in Fall 2013.

\section{From State University System}
$\%$ Graduated
\% Still Enrolled
$\%$ Success Rate

\section{USF-SM began admitting FTICs in Fall 2013.}

Notes: First-time-in-college (FTIC) cohort is defined as undergraduates entering in fall term (or summer continuing to fall) with fewer than 12 hours earned since high school graduation. (1) Cohorts are based on undergraduate students who enter the institution in the Fall term (or Summer term and continue into the Fall term). Students of degree programs longer than four years (eg, PharmD) are included in the cohorts. The initial cohorts are revised to remove students, who have allowable exclusions as defined by IPEDS, from the cohort. (2) Success Rate measures the percentage of an initial cohort of students who have either graduated or are still enrolled. (3) Since degrees can be awarded after the last semester of coursework, the most recent year of data in this table provides preliminary graduation rate data that may change with the addition of "late degrees". Late degrees reported in conjunction with the IPEDS Graduation Rate Survey due in mid-April will be reflected in the following year. 


\section{Section 4 - Undergraduate Education (continued)}

TABLE 4E. AA Transfer Progression and Graduation Rates

\begin{tabular}{rccccc}
$\mathbf{2}-$ Year Rates & $\mathbf{2 0 0 7 - 0 9}$ & $\mathbf{2 0 0 8 - 1 0}$ & $\mathbf{2 0 0 9 - 1 1}$ & $\mathbf{2 0 1 0 - 1 2}$ & $\mathbf{2 0 1 1 - 1 3}$ \\
Preliminary \\
\hline Cohort & 231 & 272 & 223 & 278 & 253
\end{tabular}

From Same University

$\begin{array}{lccccc}\% \text { Graduated } & 33 \% & 15 \% & 30 \% & 29 \% & 34 \% \\ \% \text { Still Enrolled } & 48 \% & 59 \% & 51 \% & 55 \% & 45 \%\end{array}$

From Other SUS University

$\begin{array}{lccccc}\% \text { Graduated } & 0 \% & 11 \% & 5 \% & 1 \% & 2 \% \\ \% \text { Still Enrolled } & 3 \% & 6 \% & 2 \% & 4 \% & 4 \%\end{array}$

From State University System

$\begin{array}{lccccc}\% \text { Graduated } & 34 \% & 26 \% & 36 \% & 30 \% & 36 \% \\ \% \text { Still Enrolled } & 51 \% & 65 \% & 52 \% & 59 \% & 49 \% \\ \% \text { Success Rate } & 85 \% & 91 \% & 88 \% & 89 \% & 86 \%\end{array}$

\begin{tabular}{rccccc}
$\mathbf{4}$ - Year Rates & $\mathbf{2 0 0 5 - 0 9}$ & $\mathbf{2 0 0 6 - 1 0}$ & $\mathbf{2 0 0 7 - 1 1}$ & $\mathbf{2 0 0 8 - 1 2}$ & $\begin{array}{c}\mathbf{2 0 0 9 - 1 3} \\
\text { Preliminary }\end{array}$ \\
\hline Cohort & 217 & 188 & 231 & 272 & 223
\end{tabular}

From Same University

$\begin{array}{lccccc}\% \text { Graduated } & 63 \% & 67 \% & 57 \% & 53 \% & 65 \% \\ \% \text { Still Enrolled } & 13 \% & 10 \% & 5 \% & 8 \% & 6 \%\end{array}$

From Other SUS University

$\begin{array}{lccccc}\% \text { Graduated } & 2 \% & 4 \% & 12 \% & 18 \% & 7 \% \\ \% \text { Still Enrolled } & 0 \% & 1 \% & 2 \% & 1 \% & 1 \%\end{array}$

From State University System

$\begin{array}{lccccc}\text { \% Graduated } & 65 \% & 71 \% & 69 \% & 71 \% & 72 \% \\ \% \text { Still Enrolled } & 13 \% & 11 \% & 7 \% & 9 \% & 7 \% \\ \% \text { Success Rate } & 78 \% & 82 \% & 77 \% & 80 \% & 79 \%\end{array}$

Notes: AA Transfer cohort is defined as undergraduates entering in the fall term (or summer continuing to fall) and having earned an AA degree from an institution in the Florida College System. (1) Cohorts are based on undergraduate students who enter the institution in the Fall term (or Summer term and continue into the Fall term); (2) Success Rate measures the percentage of an initial cohort of students who have either graduated or are still enrolled; (3) since degrees can be awarded after the last semester of coursework, the most recent year of data in this table provides preliminary graduation rate data that may change with the addition of "late degrees". Late degrees reported in conjunction with the IPEDS Graduation Rate Survey due in mid-April will be reflected in the following year. 


\section{Section 4 - Undergraduate Education (continued)}

TABLE 4F. Other Transfer Progression and Graduation Rates

\begin{tabular}{rccccc}
$\mathbf{5}-$ Year Rates & $\mathbf{2 0 0 4 - 0 9}$ & $\mathbf{2 0 0 5 - 1 0}$ & $\mathbf{2 0 0 6 - 1 1}$ & $\mathbf{2 0 0 7 - 1 2}$ & $\begin{array}{c}\mathbf{2 0 0 8 - 1 3} \\
\text { Preliminary }\end{array}$ \\
\hline Cohort Size & 143 & 133 & 173 & 191 & 149
\end{tabular}

From Same University

$\begin{array}{lccccc}\% \text { Graduated } & 63 \% & 59 \% & 57 \% & 54 \% & 56 \% \\ \% \text { Still Enrolled } & 2 \% & 2 \% & 5 \% & 2 \% & 7 \%\end{array}$

From Other SUS University

$\begin{array}{lccccc}\% \text { Graduated } & 3 \% & 5 \% & 5 \% & 12 \% & 13 \% \\ \% \text { Still Enrolled } & 0 \% & 2 \% & 2 \% & 2 \% & 1 \%\end{array}$

From State University System

$\begin{array}{lccccc}\text { \% Graduated } & 66 \% & 64 \% & 61 \% & 66 \% & 68 \% \\ \% \text { Still Enrolled } & 2 \% & 4 \% & 7 \% & 4 \% & 8 \% \\ \% \text { Success Rate } & 68 \% & 68 \% & 68 \% & 70 \% & 77 \%\end{array}$

Notes: (1) Cohorts are based on undergraduate students who enter the institution in the Fall term (or Summer term and continue into the Fall term); (2) Success Rate measures the percentage of an initial cohort of students who have either graduated or are still enrolled; (3) since degrees can be awarded after the last semester of coursework, the most recent year of data in this table provides preliminary graduation rate data that may change with the addition of "late degrees". Late degrees reported in conjunction with the IPEDS Graduation Rate Survey due in mid-April will be reflected in the following year. 


\section{Section 4 - Undergraduate Education (continued)} TABLE 4G. Baccalaureate Degrees Awarded

2008-09

$$
\text { Degree Count }
$$

\section{9-10}

358

\section{0-11}

454
2011-12

521
2012-13

556

Note: Table 4G represents the counts of distinct baccalaureate degrees. In those cases where baccalaureate degrees are awarded under two different degree CIPs, a distinction is made between "dual degrees" and "dual majors." Dual degrees are counted as separate degrees (i.e., counted twice), and include those cases where the second major differs substantially from the first because either the college is different, the degree designation is different (e.g., BA, BS, BBA, BFA, etc.), or the degree CIP is in a different 2-digit range (e.g., $51^{*}$ vs. $52^{*}$ ); in these cases, the second degree CIP receives a "degree fraction" of 1.0. If these conditions do not apply, the second major is considered a dual major, and the degree associated with it is not counted a second time; in these cases, each dual major degree CIP receives a degree fraction of .5 apiece. The calculation of degree fractions is made according to each institution's criteria. In those rare cases where there are three or more awarded baccalaureate degree CIPS, analogous logic is extended to cover the additional degree CIPs and their corresponding degree fractions.

\section{TABLE 4H. Baccalaureate Degrees Awarded in Programs of Strategic Emphasis}

2008-09

Science, Technology,

Engineering, and Math

Health Professions

*only disciplines in critical need

Security and Emergency

Services

Globalization

Education

*only disciplines in critical need

SUBTOTAL

Percentage of All Baccalaureate

Degrees (includes second majors)

23

16

28

0

11

78

$17 \%$
2009-10 2010-11

2011-12

2012-13

10

14

14

21

4

0

0

0

37

34

37

48

0

0

0

0

0

0

0

0

51

48

51

69

$14 \%$

$11 \%$

$10 \%$

$12 \%$

Notes: This is a count of baccalaureate majors for specific Programs of Strategic Emphasis, as determined by the Board of Governors staff with consultation with business and industry groups and input from universities. A student who has multiple majors in the subset of targeted Classification of Instruction Program codes will be counted twice (i.e., double-majors are included). * This data represents select disciplines within these five areas and does not reflect all degrees awarded within the general field (of education or health). The Board of Governors will review Board staff recommendations to update this list at their November 2013 meeting. Any changes from that meeting will be incorporated into subsequent Accountability Reports. Note: The denominator used in the percentage includes second majors that are not reported in the degree count in table $4 \mathrm{G}$. 


\section{Section 4 - Undergraduate Education (continued)}

\section{TABLE 4I. Baccalaureate Degrees Awarded to Underrepresented Groups}

\section{8-09 2009-10 2010-11 2011-12 2012-13}

\section{Non-Hispanic Black}

$\begin{array}{cccccc}\text { Number of Degrees } & 26 & 15 & 22 & 24 & 35 \\ \text { Percentage of Degrees } & 6 \% & 4 \% & 5 \% & 5 \% & 6 \%\end{array}$

\section{Hispanic}

\begin{tabular}{cccccc} 
Number of Degrees & 27 & 26 & 35 & 59 & 65 \\
Percentage of Degrees & $6 \%$ & $8 \%$ & $8 \%$ & $11 \%$ & $12 \%$ \\
\hline -Grant Recipients & & & & & \\
\hline Number of Degrees & 92 & 127 & 219 & 284 & 309 \\
Percentage of Degrees & $21 \%$ & $36 \%$ & $49 \%$ & $55 \%$ & $56 \%$
\end{tabular}

Note: Non-Hispanic Black and Hispanic do not include students classified as Non-Resident Alien or students with a missing race code. Students who earn two distinct degrees in the same term are counted twice - whether their degrees are from the same six-digit CIP code or different CIP codes. Students who earn only one degree are counted once - even if they completed multiple majors or tracks. Percentage of Degrees is based on the number of baccalaureate degrees awarded to non-Hispanic Black and Hispanic students divided by the total degrees awarded - excluding those awarded to nonresident aliens and unreported.

Pell-Grant recipients are defined as those students who have received a Pell grant from any SUS Institution within six years of graduation - excluding those awarded to non-resident aliens, who are only eligible for Pell grants in special circumstances. Percentage of Degrees is based on the number of baccalaureate degrees awarded to Pell recipients, as shown above, divided by the total degrees awarded - excluding those awarded to non-resident aliens.

Notes on Trends: In 2007, the US Department of Education re-classified the taxonomy for self-reported race/ethnicity categories and allowed universities a two-year phase-in process before all institutions were required to report based on the new categories for the 2010-11 academic year. This reclassification will impact trends. 


\section{Section 4 - Undergraduate Education (continued) TABLE 4J. Baccalaureate Degrees Without Excess Credit Hours}

\section{8-09 2009-10 2010-11 2011-12 2012-13*}

FTIC

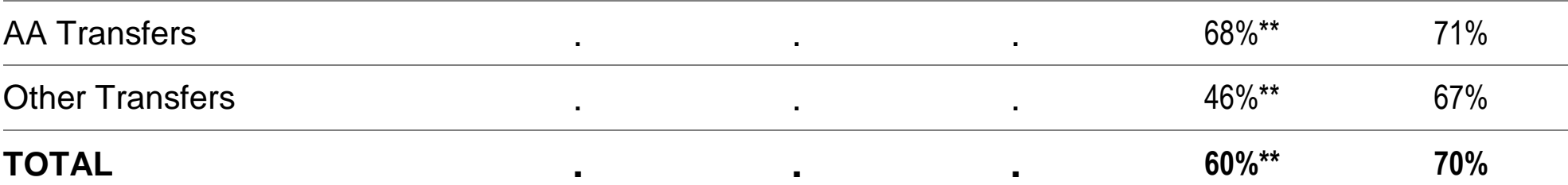

Notes: This table is based on statute 1009.286 (see link), and excludes certain types of student credits (ie, accelerated mechanisms, remedial coursework, non-native credit hours that are not used toward the degree, non-native credit hours from failed, incomplete, withdrawn, or repeated courses, credit hours from internship programs, credit hours up to 10 foreign language credit hours for transfer students in Florida, and credit hours earned in military science courses that are part of the Reserve Officers' Training Corps (ROTC) program). This metric is not the same as the Excess Hours Surcharge, which has multiple cohorts with varying fee rates. This table reports the percentage of baccalaureate degrees awarded within $110 \%$ of the catalog hours required for a degree based on the Board of Governors Academic Program Inventory. This calculation is based on Hours To Degree data submitted by universities to the Board of Governors and excludes recent graduates who have already earned a baccalaureate degree.

Note*: Improvements were made to data collection process beginning with 2012-13 data. Note $^{* *}$ :Staff are working on recalculating the data to reflect minor modifications.

\section{TABLE 4K. Undergraduate Course Offerings}

Fall 2008 Fall $2009 \quad$ Fall $2010 \quad$ Fall $2011 \quad$ Fall 2012

$\begin{array}{cccccc}\text { Number of } & 143 & 135 & 136 & 137 & 155 \\ \text { Course Sections } & 135 & & \end{array}$

Percentage of Undergraduate Course Sections by Class Size

\begin{tabular}{llllll}
\hline Fewer than 30 Students & $82 \%$ & $87 \%$ & $85 \%$ & $77 \%$ & $84 \%$ \\
\hline 30 to 49 Students & $15 \%$ & $11 \%$ & $12 \%$ & $20 \%$ & $13 \%$ \\
\hline 50 to 99 Students & $3 \%$ & $2 \%$ & $3 \%$ & $2 \%$ & $3 \%$ \\
\hline 100 or More Students & $1 \%$ & $1 \%$ & $0 \%$ & $1 \%$ & $1 \%$
\end{tabular}

Notes: This data is based on Common Data Set (CDS) definitions. According to CDS, a "class section is an organized course offered for credit, identified by discipline and number, meeting at a stated time or times in a classroom or similar setting, and not a subsection such as a laboratory or discussion session. Undergraduate class sections are defined as any sections in which at least one degree-seeking undergraduate student is enrolled for credit. Exclude distance learning classes and noncredit classes and individual instruction such as dissertation or thesis research, music instruction, or one-to-one readings. Exclude students in independent study, co-operative programs, internships, foreign language taped tutor sessions, practicums, and all students in one-on-one classes. 


\section{Section 4 - Undergraduate Education (continued)}

TABLE 4L. Percentage of Undergraduate Credit Hours Taught by Instructor Type

\begin{tabular}{lccccc} 
& $\mathbf{2 0 0 8 - 0 9}$ & $\mathbf{2 0 0 9 - 1 0}$ & $\mathbf{2 0 1 0 - 1 1}$ & $\mathbf{2 0 1 1 - 1 2}$ & $\mathbf{2 0 1 2 - 1 3}$ \\
\hline Faculty & $58 \%$ & $60 \%$ & $64 \%$ & $65 \%$ & $62 \%$ \\
\hline Adjunct Faculty & $39 \%$ & $38 \%$ & $34 \%$ & $34 \%$ & $37 \%$ \\
\hline Graduate Students & $3 \%$ & $1 \%$ & $1 \%$ & $0 \%$ & $1 \%$ \\
\hline Other Instructors & $0 \%$ & $1 \%$ & $1 \%$ & $1 \%$ & $0 \%$
\end{tabular}

Note: The total number of undergraduate state fundable credit hours taught will be divided by the undergraduate credit hours taught by each instructor type to create a distribution of the percentage taught by each instructor type. Four instructor types are defined as faculty (pay plans 01, 02, and 22), OPS faculty (pay plan 06), graduate student instructors (pay plan 05), and others (all other pay plans). If a course has more than one instructor, then the university's reported allocation of section effort will determine the allocation of the course's total credit hours to each instructor. The definition of faculty varies for Tables 4L, 4M and 4N. For Faculty Teaching Undergraduates, the definition of faculty is based on pay plans 01,02 , and 22.

\section{TABLE 4M. Student/Faculty Ratio}

\section{Fall 2008 Fall $2009 \quad$ Fall $2010 \quad$ Fall $2011 \quad$ Fall 2012}

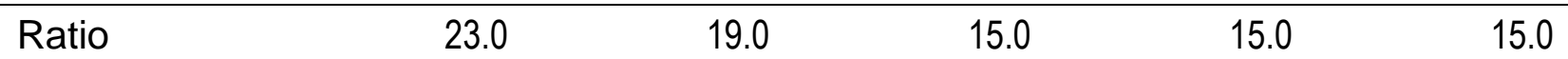

Note: This data is based on Common Data Set (CDS) definitions. This is the Fall ratio of full-time equivalent students (full-time plus $1 / 3$ part time) to fulltime equivalent instructional faculty (full time plus $1 / 3$ part time). In the ratio calculations, exclude both faculty and students in stand-alone graduate or professional programs such as medicine, law, veterinary, dentistry, social work, business, or public health in which faculty teach virtually only graduatelevel students. Do not count undergraduate or graduate student teaching assistants as faculty. 


\section{Section 5 - Graduate Education}

\section{TABLE 5A. Graduate Degree Program Changes in AY 2012-13}

\begin{tabular}{|c|c|c|c|c|c|c|}
\hline Title of Program & $\begin{array}{l}\text { Six-digit } \\
\text { CIP } \\
\text { Code }\end{array}$ & $\begin{array}{c}\text { Degree } \\
\text { Level }\end{array}$ & $\begin{array}{l}\text { Date of } \\
\text { UBOT } \\
\text { Action }\end{array}$ & $\begin{array}{l}\text { Starting } \\
\text { or Ending } \\
\text { Term }\end{array}$ & $\begin{array}{l}\text { Date of } \\
\text { Board of } \\
\text { Governors } \\
\text { Action }\end{array}$ & Comments \\
\hline \multicolumn{7}{|l|}{ New Programs } \\
\hline Education, General & 13.0101 & M & $12 / 13 / 2012$ & Fall 2013 & & \\
\hline \multicolumn{7}{|l|}{ Terminated Programs } \\
\hline \multicolumn{7}{|l|}{ None } \\
\hline \multicolumn{7}{|l|}{ Inactive Programs } \\
\hline None & & & & & & \\
\hline \multicolumn{7}{|c|}{ New Programs Considered By University But Not Approved } \\
\hline None & & & & & & \\
\hline
\end{tabular}

Note: This table does not include new majors or concentrations added under an existing degree program CIP Code. This table reports the new and terminated program changes based on Board action dates between May 5, 2012 and May 4, 2013.

New Programs are proposed new degree programs that have been completely through the approval process at the university and, if appropriate, the Board of Governors. Does not include new majors or concentrations added under an existing degree program CIP Code.

Terminated Programs are degree programs for which the entire CIP Code has been terminated and removed from the university's inventory of degree programs. Does not include majors or concentrations terminated under an existing degree program CIP Code if the code is to remain active on the academic degree inventory.

Inactive Programs are degree programs for which enrollments have been temporarily suspended for the entire CIP Code, but the program CIP Code has not been terminated. Does not include majors or concentrations suspended under an existing degree program CIP Code if the code is to remain active on the academic degree inventory and new enrollments in any active major will be reported.

New Programs Considered by University But Not Approved includes any programs considered by the university board of trustees, or any committee of the board, but not approved for implementation. Also include any programs that were returned prior to board consideration by the university administration for additional development, significant revisions, or re-conceptualization; regardless of whether the proposal was eventually taken to the university board for approval. Count the returns once per program, not multiple times the proposal was returned for revisions, unless there is a total re-conceptualization that brings forward a substantially different program in a different CIP Code. 


\section{Section 5 - Graduate Education (continued)}

\section{TABLE 5B. Graduate Degrees Awarded}

\begin{tabular}{lccccc} 
& $\mathbf{2 0 0 8 - 0 9}$ & $\mathbf{2 0 0 9 - 1 0}$ & $\mathbf{2 0 1 0 - 1 1}$ & $\mathbf{2 0 1 1 - 1 2}$ & $\mathbf{2 0 1 2 - 1 3}$ \\
\hline \multicolumn{1}{c}{ TOTAL } & 125 & 59 & 68 & 72 & 60 \\
\hline Masters and Specialist & 125 & 59 & 68 & 72 & 60 \\
\hline Research Doctoral & 0 & 0 & 0 & 0 & 0 \\
Professional Doctoral & 0 & 0 & 0 & 0 & 0 \\
\hline a) Medicine & 0 & 0 & 0 & 0 & 0 \\
b) Law & 0 & 0 & 0 & 0 & 0 \\
c) Pharmacy & 0 & 0 & 0 & 0 & 0
\end{tabular}

Note: The total number of Professional Doctoral degrees includes other programs that are not specifically identified in lines $a, b$, and $c$.

Note: In preparation for separate SACS accreditation, USF Sarasota-Manatee discontinued several master's level programs in 2009-10 that were offered through USF Tampa. In addition, there has been a decline in demand for master's degrees in Education.

\section{TABLE 5C. Graduate Degrees Awarded in Areas of Strategic Emphasis}

\section{8-09 2009-10 2010-11 2011-12 2012-13}

Science, Technology,

Engineering, and Math

Health Professions

*only disciplines in critical need

Security and Emergency

Services

Globalization

Education

*only disciplines in critical need

SUBTOTAL

Percent of All

Graduate Degrees
10

7

3

0

13

33

$26 \%$

0

4

4

0

12

20

$34 \%$

$31 \%$

21

19

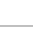

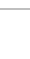

$\%$

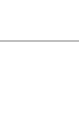

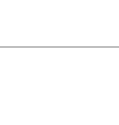

Notes: This is a count of graduate degrees awarded within specific Areas of Strategic Emphasis, as determined by the Board of Governors staff with consultation with business and industry groups and input from universities. A student who has multiple majors in the subset of targeted Classification of Instruction Program codes will be counted twice (i.e., double-majors are included). ${ }^{*}$ This data represents select disciplines within these five areas and does not reflect all degrees awarded within the general field (of education or health). Note: The denominator used in the percentage includes second majors that are not reported in the degree count in table $5 B$. 


\section{Section 6 - Research and Economic Development}

TABLE 6A. Research and Development

\section{7-08 2008-09 2009-10 2010-11 2011-12

\section{R\&D Expenditures}

Total (S\&E and non-S\&E)

(\$1,000s)

Federally Funded

(\$1,000s)

Percent Funded

From External Sources

Total R\&D Expenditures

Per Full-Time, Tenured,

Tenure-Earning Faculty

Member (\$)

\section{Technology Transfer}

Invention Disclosures

\section{U.S. Patents Issued}

Patents Issued Per 1,000

Full-Time, Tenured and

Tenure-Earning Faculty

Licenses/ Options Executed
Campus R\&D data
is not available
for these
historical years.

\begin{tabular}{rcc}
\hline 732 & $\$ 914$ & $\$ 784$ \\
\hline$\$ 106$ & $\$ 191$ & $\$ 115$ \\
\hline $17 \%$ & $31 \%$ & $20 \%$ \\
\hline$\$ 22,750$ & $\$ 28,563$ & $\$ 21,189$ \\
\hline
\end{tabular}

Licensing Income

Received (\$)

\section{Number of Start-Up}

Companies

Note: R\&D Expenditures are based on the National Science Foundation's annual Survey of R\&D Expenditures at Universities and Colleges (data include Science \& Engineering and non-Science \& Engineering awards). Percent Funded from External Sources is defined as funds from federal, private industry and other sources (non-state and non-institutional funds). Total R\&D expenditures are divided by fall, full-time tenured/tenure-track faculty as reported to IPEDS (FGCU includes both tenured/tenure-track and non-tenure/track faculty). The fall faculty year used will align with the beginning of the fiscal year, so that (e.g.) 2007 FY R\&D expenditures are divided by fall 2006 faculty. Technology Transfer data are based on the Association of University Technology Managers Annual Licensing Survey. Licensing Income Received refers to license issue fees, payments under options, annual minimums, running royalties, termination payments, amount of equity received when cashed-in, and software and biological material end-user license fees of $\$ 1,000$ or more, but not research funding, patent expense reimbursement, valuation of equity not cashed-in, software and biological material end-user license fees of less than $\$ 1,000$, or trademark licensing royalties from university insignia. Number of Start-up Companies that were dependent upon the licensing of University technology for initiation. 